\title{
A Dor no Processo Morte e Morrer Enfrentado Pelo Profissional de Enfermagem.
}

\author{
Rodrigues, Carla Fernanda de Miranda; Conceição, Sandra Maria da Penha \\ Centro Universitario Anhanguera — cafemiro@gmail.com
}

Introdução no Brasil, existe uma cultura acolhedora na nossa sociedade, os profissionais de enfermagem no seu atendimento ligados com a humanização possuem sentimentos pessoais que se envolvem com o paciente, de modo a demonstrar seus cuidados diários nos serviços prestados. São situações em que os profissionais estão expostos com muita frequência durante diversas situações que levam ao processo do morrer e que se torna em um momento a morte. a formação destes profissionais se torna um desafio para o corpo docente, ensinando a lidar com os sentimentos e suas emoções mais profundas. Objetivos Propor uma reflexão sobre os sentimentos de dor enfrentados pelo profissional de enfermagem no processo morte e morrer durante suas atividades. Métodos Estudo de natureza qualitativa e descritiva, desenvolvido por meio de uma revisão sistemática da literatura ,nas bases de dados do sitio da biblioteca Virtual em Saúde - BVS- BIREME, Llilacs, Medline e Scielo, levantou-se 54 artigos no período de 2003 até 2013. Seguindo critérios de inclusão sendo artigos brasileiros, internacionais, gratuito e na íntegra. Resultados: na busca da leitura de uma forma crítica destes títulos os estudos mostraramse que a busca de estratégias para o enfrentamento diante da morte devem ser estabelecidas. Oferecer um acompanhamento profissional para este individuo que lida com outras vidas se torna importante, o enfrentamento caracterizado no processo que passa pelas cinco fases do luto como: negação, raiva, barganha, depressão e aceitação. para que se obtenha eficácia e sucesso do acompanhamento a este quadro clinico o enfermeiro necessita estar capacitado emocionalmente. Sabendo lidar com os seus sentimentos e emoções que são geradas diante de tal situação. nos estudos vemos que são negativas para o ser humano sendo elas; medo, sofrimento, culpa, tristeza, angustia, dor, fracasso, sofrimento, impotência, erro, levando a frieza por parte de muitos indivíduos. Considerações Finais: a morte e o morrer são processos da vida que geram a ausência, o ser humano tem dificuldades de enfrentar as perdas de qualquer situação, aprendemos que devemos superar conquistar, adquirir, enfrentar e seguir em frente. Porem como seguir em frente com o termino de uma vida, algo que não se reconquista. Pesquisas mostram que docentes com maior experiência profissional e com a vida mais madura, estão mais capacitadas para transmitir a ideia de como lidar com este perfil de paciente. Tudo para se aprender precisa de treino para se adquirir habilidade e como se habilitar a morte? o final sem volta para os que ficam e para aqueles que partem. Identificar e passar pelas fases do luto ajudam os profissionais a aceitarem a situação de modo a não interferir no profissional ou no pessoal do individuo. Palavras chaves: dor; enfermagem; morte e morrer.

Rodrigues, Carla Fernanda de Miranda; Conceição, Sandra Maria da Penha. A Dor no Processo Morte e Morrer Enfrentado Pelo Profissional de Enfermagem.. In: Anais do Congresso Internacional de Humanidades \& Humanização em Saúde [= Blucher Medical Proceedings, num.2, vol.1]. São Paulo: Editora Blucher, 2014. ISSN 2357-7282

DOI 10.5151/medpro-cihhs-10291 